drops, or at least of small spheres, and not of erystals. ${ }^{4}$ The same reasoning would indicate that the iridescent clouds of the stratosphere are also composed of drops ; but there is so little water vapour in the stratosphere that it is difficult to see how clouds of the density described by Størmer can be formed.

The high luminous night clouds are supposed to derive their water from the volcanic eruptions with which they appear to be associated-they were particularly bright from 1883 to 1889 after the Krakatoa eruption-but the close association of the iridescent stratosphere clouds with a particular type of weather appears to make this explanation unsuitable for them.

It is quite clear that there is still a great deal to learn about the physical state of the upper atmosphere.

Meteorological Office, London, G. C. SIMPSON. April 19.

1 Natore, Feb. 16, 1929, p. 260.

2 Nature, A pril 2, 1932, p. 497

"See "Meteorologische Optik", by Pertner-Exner, second edition, p. 460 .

Simpson, Quar. J. Roy, Met. Soc., 38, 291; 1912

In Nature of April 2, Prof. Chapman has an interesting article on the iridescent (mother-of-pearl) clouds observed by Prof. Størmer of Oslo. These clouds, which are unmistakable in appearance, are reported to have been at the great height of 26 to $30 \mathrm{~km}$. I once discussed these clouds with the late Prof. Mohn, but there was then no suggestion that they floated so high. Their appearance at the altitude now recorded opens up some interesting problems.

The clouds are to be seen from time to time at sea : it was my custom to call them "fish-scale colour clouds' and to associate them with bad weather.

The reports of luminous ' night clouds' have always puzzled me, and although I spent a great deal of time in the open air, I have never seen them, nor have I ever met any seaman who has. Is it possible, however, that there may be some connexion between this great altitude and luminosity ?

DAVID WILSON-BARKER.

Royal United Service

Institution, S.W.1.

\section{Hexuronic Acid as the Antiscorbutic Factor}

WE have reported in a previous note, ${ }^{1}$ that with a daily dosage of $1 \mathrm{mgm}$. hexuronic acid guinea-pigs were kept free from symptoms of scurvy for fifty-five days. This experiment was continued to the ninetieth day. During this time all animals receiving hexuronic acid showed normal growth. On the ninetieth day all animals were chloroformed, and on autopsy were found entirely free from scurvy. The animals receiv. ing I c.c. of lemon juice showed mild scurvy. The experiment was completed with all the necessary controls.

Since the hexuronic acid used was prepared from animal sources (adrenal glands), no objection can arise that the observed antiscorbutic activity was due to a contamination by a more potent antiscorbutic substance. The daily dose of hexuronic acid employed was of the same magnitude as the hexuronic acid content of the protective dose of lemon juice ( 1.5 c.c.). It is generally accepted that animals surviving ninety days with no symptoms of scurvy on autopsy and showing normal growth could be kept indefinitely free from scurvy under identical conditions. This allows us to conclude that vitamin $C$ is a single substance and identical with hexuronic acid.

Simultaneously with our previous note, C. G. King and W. A. Waugh ${ }^{2}$ reported that they have obtained, from lemon juice, crystals which showed antiscorbutic activity and were apparently similar in chemical and physical properties to hexuronic acid. The duration of the test period was not stated, and apparently no chemical analysis was made. Until this is done, the nature of their product remains in doubt.

This research was sponsored by the Ella Sachs Plotz Foundation.

\section{J. L. SVIRBELy.*}

A. SZENT-GYöRGYI.

Institute of Medical Chemistry,

University Szeged, Hungary, April 22.

* Holder of an American-Hungarian Exchange Fellowship, 1931-32, from the Institute of International Education, New York.

2 NATURE, April 16, p. 576.

2 Science, vol. 75, No. 1944, April 1, 1932.

Ever since Prof. A. Szent-Györgyi suggested the possible identity of hexuronic acid ${ }^{1}$ with the 'reducing principle' present in all active antiscorbutic solutions, I have been experimenting at various periods in this connexion. These experiments led me to the conclusion that the likelihood of ' hexuronic acid' being identical with the antiscorbutic factor was small, but I much regret that owing to illness I am at the moment precluded from supplying from my experimental notes the relevant data which seem to me to justify this provisional conclusion. Moreover, in view of $\mathrm{J}$. L. Svirbely and Prof. A. Szent-Györgyi's claims referred to in NATURE of April 16, my previous experimental work on the subject will have to be further amplified, and therefore I cannot now enter into a detailed discussion of the matter. It is my intention, however, to make in this note only one or two comments on Svirbely and Szent-Györgyi's results.

According to Svirbely and Szent-Györgyi, 1 milligram of hexuronic acid was found to offer a marked protection against scurvy in guinea-pigs, and they justly assert that the activity of this compound is most probably higher, but that, owing to its long exposure to air, a loss of the vitamin has occurred and consequently the minimum dose would be lower than $1 \mathrm{mgm}$. They further state that 1.5 c.c. of lemon juice, the minimum protective dose for guineapigs against scurvy, is equivalent to $0.5 \mathrm{mgm}$. of hexuronic acid, thus implying that the minimum dose of the antiscorbutic factor is about $0.5 \mathrm{mgm}$. of hexuronic acid. In this connexion it must be pointed out that such minimum doses have been obtained by other workers and myself with fractions from lemon juice which were evidently grossly contaminated. This fact militates rather against the contention that hexuronic acid and the antiscorbutic factor are identical. The interesting point that emerges, in my opinion, from Svirbely and Szent.Györgyi's data is that it is possible to prepare active fractions of the antiscorbutic factor from a definite animal tissue.

Division of Nutrition,

S. S. ZiLva.

Lister Institute, London.

1 A. Szent-Györgyi, Biochem. J., 22, 1387; 1928.

Occurrence of 'Gleistogenes' in certain Grasses

BeDDows ${ }^{1}$ has raised some interesting points regarding Triodia decumbens, particularly as regards the occurrence of 'cleistogenes' at the base of the fertile tillers in the cleistogamous form. Subsequent investigation of their structure has shown that these 'cleistogenes' may contain as many as three florets. Structures are present within their enveloping prophyll which possibly represent empty glumes ; these, however, are by no means consistent either as to form or presence. The fertile florets, on the other hand, have well-developed flowering glume and palea. The three

No. 3262, VoL. 129] 